\title{
Regulatory Review and Cost-Benefit Analysis
}

\author{
Mark Sagoff
}

$\mathrm{I}_{\mathrm{a}}^{\mathrm{n}}$ n a Memorandum issued within a few days after he assumed office, President Barack Obama called for an overhaul of the policies the White House uses to review regulations proposed by federal departments and agencies. The president acknowledged the necessity of regulatory review "to ensure consistency with Presidential priorities, to coordinate regulatory policy, and to offer a dispassionate and analytical 'second opinion' on agency actions." Critics of previous administrations had charged that they misused the process of regulatory review to thwart agency actions. "In this time of fundamental transformation," the president wrote, "that process - and the principles governing regulation in general-should be revisited." Regulatory agencies have missions-but they must also consider the economic costs and consequences of what they do. This essay considers how the White House, in reviewing regulations, can direct agencies to take these costs and consequences into account while letting them do their work.

\section{Regulatory Review}

From the time of the Reagan administration, federal agencies, including the Environmental Protection Agency (EPA), and departments, such as the Department of Labor and the Department of Agriculture, have had to obtain the approval of the White House before proposing any major regulation. Each year, the White House through its Office of Information and Regulatory Affairs (OIRA) in the Office of Management and Budget (OMB) reviews about 500 rulemakings. Those it approves may become law; those it rejects it "returns" to the agency.

The Executive Order that currently governs regulatory review within OIRA requires every department and agency that proposes a regulation to "assess both the costs and the benefits of the intended regulation" and to "propose or adopt a regulation only upon a reasoned determination that the benefits of the intended regulation justify its costs." This requirement may seem innocuous; that agencies should balance the benefits and costs of a regulation appears to make common sense. Yet over the past 30 years, economists have developed a formal and technical method of defining and measuring "costs" and "benefits." Agencies must package regulatory proposals in a way that passes a cost-benefit test in the specific and technical sense that "costs" and "benefits" are now defined and measured within the theory of microeconomics.

Within microeconomic theory, benefits are measured in terms of the amount people are willing to pay for outcomes they want. In economic parlance, "benefit" and "willingness to pay" (WTP) refer to the same thing. According to one authoritative text, "Benefits are the sums of the maximum amounts that people would be willing to pay to gain outcomes that they view as desirable." Costs are measured in terms of the minimum amounts people demand as compensation (or are willing to accept) to allow outcomes they do not like. "Willingness to accept" (WTA) is counted as a kind of negative WTP. Economists measure the "net benefits" of a policy as the sum of the WTP (including negative WTA) of all those people it affects. Economic theory dictates, "Adopt all policies that have net positive benefits" or, more generally, "Choose the combination of policies that maximizes net benefits."

The directive to "assess both the costs and the benefits of the intended regulation" does not invite agencies to discuss the reasons for and against a policy. No one would object to that kind of invitation. Instead, the directive is interpreted to presuppose the reason for any rulemaking, that is, to maximize net benefits. To meet the conditions OIRA sets for regulatory approval, an agency must think in terms of net WTP from the time it begins a rulemaking. To obtain OIRA approval, the agency must also show that no alternative regulation achieves a better balance between benefits and costs, as these are defined and measured within the two corners-WTP and WTA of microeconomic theory. 
Many economists believe that this scientific approach to regulation is more reliable than any political process. "In general," as one textbook advises, "politicians prefer projects that concentrate benefits on particular interest groups and camouflage costs or diffuse them widely over the population." As a prominent environmental economist has written, "It is the politician's job to compromise or seek advantage," while because economists are scientists they "produce studies that are ... as objective as possible." There may be some truth in these remarks. Surely, agencies do sometime go overboard, for example, if they publish regulations that place enormous burdens on industry to prevent tiny risks to society. Surely the White House can legitimately provide a "second opinion" on whether a regulation is needed or is reasonable given its costs. If cost-benefit analysis (CBA) is not the right method, what is?

In his one-page Memorandum, President Obama asked for a discussion of "the principles governing regulation in general" and regulatory review in particular. What are these principles? A look at the history of regulation over the last century will help answer this question.

\section{Regulation Before the Second World War}

In the early $20^{\text {th }}$ century, Progressives (as these reformers called themselves) advocated two kinds of regulation-regulation to assure economic prosperity and regulation to improve social conditions. Progressives like Louis Brandeis, who associated themselves with Woodrow Wilson's New Freedom, believed that the concentration of economic power in the hands of industrial and financial monopolies or "trusts" slowed or stymied economic growth. These reformers succeeded in enacting statutes that sought to regulate the economy, for example, by abolishing anti-competitive practices, including high tariffs, that allowed big business to stifle competition and to collude on prices. Progressives enacted economic regulations, for example, under the Clayton Antitrust Act of 1914 to open markets to competition, encourage innovation, stimulate employment, control inflation, increase consumer and investor confidence, and otherwise promote the kind of general prosperity that "lifts all boats" and supports the American Dream.

During the New Deal many regulations similarly emphasized economic growth and recovery, that is, the performance of the economy. Some of the regulatory agencies established during the Depression to help the nation along the path to prosperity, such the Federal Deposit Insurance Corporation and the Securities and Exchange Commission, still exist today. The goals of these agencies-and of the regulations they issue-are explicitly economic, but they turn not on microeconomic but on macroeconomic measures, that is, measures of the performance of the overall economy. The way macroeconomists assess economic performance has to do with employment, inflation, interest rates, productivity, technological progress, and the stability of the business cycle, among other indicators. These macroeconomic concepts, the

\section{While economic regulations try to make the economy more prosperous, social regulations seek to make it more humane.}

importance of which is easy to understand, have no clear connection with WTP, WTA, or the maximization of net benefits-in other words, no relation to the goals of regulation as they are construed by CBA or by microeconomists.

Progressives associated with the New Nationalism of Theodore Roosevelt concerned themselves not so much with the growth of the economy-employment, inflation, and so on-as with the state of society. They were alarmed by the terrible conditions muckraking journalists like Upton Sinclair had exposed in the nation's sweatshops, slums, and mines. Progressives enacted social regulations, such as child labor laws, workplace safety standards, and minimum wage requirements, among other humanitarian programs. These reformers concerned themselves with the plight of Americans whose boats were not lifted.

While economic regulations try to make the economy more prosperous, social regulations seek to make it more humane. To do so, social regulations sometimes limit the liberty of people to make their own bargains. Child labor laws, for example, keep parents from sending their children to work in the mines. Mining companies often preferred to hire children not only because children could be paid less but also because smaller shafts could accommodate them. At a time when people were willing to accept unconscionable working conditions, laws that required workplaces to be safer and workdays to be shorter and workers to be older might not have passed a cost-benefit test. In the laissez-faire markets of the turn of the $20^{\text {th }}$ century life was cheap. In the absence of regulation it might still be cheap today.

In a famous case, Lochner v. New York (1905), the Supreme Court reviewed an ordinance that protected the health and safety of bakers by limiting to ten hours a day and six days a week the time they tended ovens. The Court struck down the ordinance as an "unreasonable, unnecessary and arbitrary interference with the right and liberty of the individual to contract." The bakers and their bosses willingly struck their own bar- 


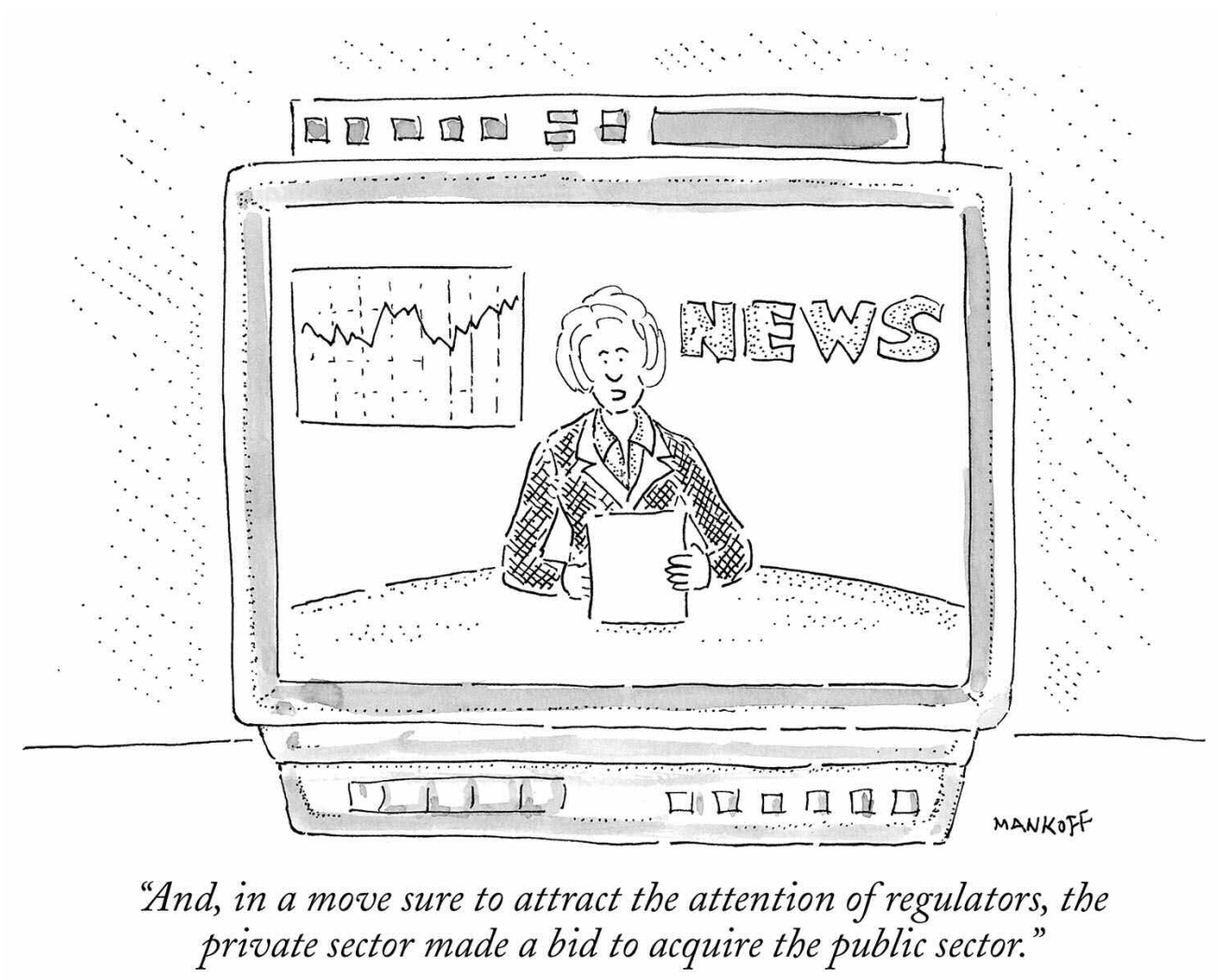

(The New Yorker)

gains, and since WTP of the bosses was greater than WTA of the bakers, the market operated efficiently. From the perspective of a cost-benefit test, this maximized net benefits no matter how many bakers got sick or died. As long as the market operated efficiently-with each person contracting freely-the

Today, we look at the Lochner decision with dismay. And we think that regulation was justified if it spared the lives of bakers who might otherwise have perished in the heat of their ovens.

results may be said to be "beneficial" and politicians may be said to "seek advantage" if they advocate reform. Today, we look at the Lochner decision with dismay. And we think that regulation was justified if it spared the lives of bakers who might otherwise have perished in the heat of their ovens.

As late as 1970, when Congress enacted the Occupational Safety and Health Act, it estimated that 14,000 Americans had died that year from job-related hazards. Almost 400,000 new cases of occupational diseases were reported. These horrors resulted from free and competitive markets in which the risks were well known-they were legendary-for example to those who worked on railroads, in construction, and in the mines. Workplace safety regulation raised the consciousness of both employers and employees by putting a floor under bargaining. Bernard Kleiman, then a negotiator for the Steelworkers, argued regulation was needed to change the WTP and WTA of workers and employers. "Both sides have to be hit over the head a good deal before they develop the consciousness that permits them to move," he said.

\section{Regulation after the Second World War}

The reformers of the 1960s and 1970s, to whom we owe a tide of environmental, health-and-safety, civil rights, and other social regulation, lived during comparatively prosperous times. The problems they addressed were less economic than social and political, having to do with segregation, racism, education, health, safety, equality of opportunity, and the environment. In the late 1960s and 1970s, outraged by the 
pollution of water and air, environmentalists succeeded in enacting many far-reaching and powerful environmental statutes. The environmental movement did not base its arguments on a theory of market efficiency or on a vision of laissez-faire capitalism. Environmentalists expected the economy to prosper, of course; that is basic to everything. They wanted to build a better society, however, by emphasizing the tranquil, the natural, the beautiful, the safe, the healthful, and the very long run.

The generation of the New Frontier of John Kennedy and the Great Society of Lyndon Johnson differed in outlook and experience from the generation of the New Deal. Its political agenda differed as well. In the 1930s and 40s the government had reformed markets to salvage capitalism (then challenged by socialism) as an ideal. In the 1960s and 1970s, in contrast, Congress tried to reform society (by enacting environmental and workplace safety regulations, for example) and itself (by promoting civil and voting rights).

Insofar as economic regulation appeared on the political agenda of the 1960s and 1970s, it centered on the deregulation of industries in which the government

\section{The trend toward economic deregulation profoundly affected the banking and financial industries; it was implicated in the meltdown of financial markets last year.}

during and after the New Deal had set prices, such as the railroads, airlines, and telecommunications. The emphasis Louis Brandeis had earlier placed on restoring competition reasserted itself in the program of economic deregulation that the Ford and Carter administrations pursued actively and successfully, for example, by letting airlines compete rather than having the government determine fares. The trend toward economic deregulation profoundly affected the banking and financial industries; it was implicated in the meltdown of financial markets last year.

When Ronald Reagan took office in 1981, the speedy and successful pursuit of economic deregulation under his predecessors created high expectations among his supporters that similar results could be achieved in the area of social deregulation. The Reagan administration sought particularly to lighten the regulatory burden environmental and workplace statutes had placed on industry. David Stockman, who became Reagan's director of OMB, called in his 1980 "Dunkirk" memo for a "dramatic, substantial rescission of the regulatory burden" and for a "regulatory ventilation." In this spirit, President Reagan issued Executive Order 12,291, which established OIRA, mandated a formal process for White House review of rulemaking, and required major regulations to pass a cost-benefit test. "Regulatory action shall not be undertaken unless the potential benefits to society for the regulation outweigh the potential costs to society," the Order stated; "Regulatory objectives shall be chosen to maximize the net benefits to society."

The call for regulatory rescission during the Reagan years was more libertarian than utilitarian. It had more to do with limiting the role of government than with improving the efficiency of markets. A widely cited article published in the Harvard Law Review during the Reagan years declared that the process of regulatory review Reagan ordered "imposes costly delays that are paid for through the decreased health and safety of the American public." As President Reagan employed it, CBA served as mainly a procedural device that proved friendly to industry by slowing or halting the flow of regulation.

The use of CBA by a president to impede federal programs was not new. President Carter had earlier required CBA in order to stall and eventually halt some pork barrel projects he opposed. As early as the 1930s, the River and Harbor Act created a Board of Engineers to weigh the commercial benefits of public works projects - such as dams built to provide irrigation and hydroelectric power-against their costs. Cost-benefit analysis in this sense depends on the same intuitive and pre-theoretical knowledge as would characterize a child's lemonade stand. Will the product-for example, water for irrigation and drinking and hydroelectric power - sell at a profit in view of the cost of labor, land, and materials? This intuitive sort of cost-benefit analysis envisions the government as if it were a firm engaged in profit-making activity. With respect to certain public works projects, such as bridges and dams, this analogy may be appropriate. Economists speak of the profit of a public works project as its "internal rate of return."

It is a nice question whether President Reagan wrote a cost-benefit test into his Executive Order because he viewed most federal programs pejoratively in terms of public works projects and pork barrel politics. It is more likely, however, that Reagan used CBA to add a layer of bureaucracy by which the White House could delay regulation, take ex parte comment on it, or simply return to the sender whatever rules it did not like. The application of CBA not just to public works projects, such as dams, but to all social and economic rulemakings, however, had an unintended effect: it turned the microecnomic theory of CBA into a talisman of government. Values, beliefs, arguments, anything people cared about could be assigned a WTP or WTA and transformed into a datum for economic analysis. Executive Order 12,291 (as lightly amended by President Bill Clinton) has served as an Open Sesame 
to allow microeconomists into the Cave of Regulation. At last the treasures belonged to them.

\section{Alternatives to CBA}

In his Memorandum, President Obama asked for comments on transforming regulatory review including "suggestions on the role of cost-benefit analysis." One may argue that CBA, at least if practiced intelligently, can provide a context for making the reasons for and against a regulation more transparent. Certainly, the technique may help to distinguish worthwhile public works projects from bridges to nowhere. To make sure that regulations are cost-conscious, however, OIRA and the agencies do not have to define costs as WTA and benefits as WTP or substitute an abstraction-net benefits maximization-for the goals Congress delegates to federal departments and agencies. Alternatives to CBA can succeed better in getting the agencies to look before they leap. To list a few of these alternatives:

\section{1) Cost-effectiveness analysis}

Cost-effectiveness analysis directs an agency to find the least costly measures to reach a given goal, even incrementally, while CBA improperly determines regulatory ends as well as means. CBA requires the decision maker to choose a particular end-net benefits maximization - while cost-effectiveness analysis compares alternative means to achieve goals set through a political process. One problem with CBA is that it tends to reinforce the status quo since it responds to "given" preferences. Cost-effectiveness analysis allows

Cost-effectiveness analysis allows society to raise its consciousness, for example, about safety, health, and the environment, while still taking costs into account.

society to raise its consciousness, for example, about safety, health, and the environment while still taking costs into account.

\section{2) Risk-risk analysis}

In limiting or preventing one risk, a regulation may produce another that is greater. The dangers that may result from a regulatory decision should be understood and compared with those it is intended to prevent.

3) A presumptive floor and ceiling (benchmark) for the cost of saving a statistical life or avoiding a statistical injury

If the goal of regulating risk were simply to avoid needless deaths or injuries, then it would make sense for agencies to spend no more to save the "next" life or prevent the "next" injury through one program than through any other. In econospeak, the marginal cost of lives saved or injuries avoided should be equalized across programs. In spite of this, because risks differ in their moral and social qualities-some are more dreadful, involuntary, unfamiliar, etc. than others-deviations may be morally explicable or even praiseworthy. Reasons should be given to explain great deviations. As Cass Sunstein, whom the president has appointed to head OIRA, has written, "If an agency is going to spend (say) no more than $\$ 500,000$ per life saved, or more than \$20 million, it should explain itself."

4) Knee-of-the-curve analysis

In many or most industries, the first reductions in pollution are the least expensive to make; eventually the cost of controlling the "next" or "incremental" unit of pollution increases. At some given state of technology, one can often find an inflection point or "knee-ofthe-curve" - a point at which the cost of controlling the "next" or marginal unit of pollution increases rapidly and returns to the environment diminish rapidly per dollar spent. One morally acceptable way to allow some pollution may be continually to encourage or prod industry to improve its processes and technologies to move the knee of the curve-the point at which costs may go asymptotic-ever farther out along the pollution-control axis. To the extent the government can encourage industries, through incentives and threats, to invent environment-friendly technology it can assure environmental progress while permitting at a given stage of technology a minimum amount of pollution necessary for economic growth.

5) Economic impact analysis

People care about the effect of regulation on the economy-on jobs, inflation, competitiveness, and the distribution of wealth. Agencies and departments may reasonably be required to identify the macroeconomic effects of proposed regulations. Cost-benefit analysis concerns microeconomic efficiency-something that interests welfare economists - but has no clear relation to things like employment and inflation, which actually matter. It makes sense to ask how a major regulation will affect the "misery index"-e.g., involuntary unemployment and inflation. The use of CBA relies on microeconomic theory and does not reach the indicators of macroeconomic performance that people care about.

\section{6) Heuristic accounting}

It may well make sense that OIRA ask agencies to provide rich or thick descriptions of the reasons for and against a policy given the costs and the alternatives. These explanations will be salutary. CBA in contrast represents a highly professionalized and technical kind of analysis that presupposes only one reason for regulation-the maximization of net benefits. The measurement of WTP and WTA has become by now a quite technical—one might even say cabbalistic — science. From a common sense point of view, it seems reasonable to ask agencies to carefully explain the 
advantages and disadvantages of regulations in view of alternatives. The relation between advantages and disadvantages and WTP and WTA is anything but clear and intuitive.

As the president composes a new Executive Order he has asked for suggestions about, among other things, the role of cost-benefit analysis in the White House review of regulations. At first glance, it seems reasonable for the White House to ask agencies to identify the benefits and costs of a regulation. A problem arises, however, because economists understand "benefits" and "costs" as WTP and WTA rather than more generally as reasons for and against a regulation. If the president even mentions the words "costs and benefits" in his Executive Order he will be interpreted as issuing a call to all economists to get on deck as consultants to measure WTP and WTA and thus sink the regulatory ship under the weight of technical and methodological controversies and conundrums. The new Executive Order should require agencies and departments to justify proposed regulations in terms of the reasons for and against them and in view of their costs. With respect to CBA, however, silence would be golden.
Mark Sagoff

Institute for Philosophy and Public Policy msagoff@umd.edu

Sources: Presidential Memorandum of January 30, 2009, “Regulatory Review: Memorandum for the Heads of Executive Departments and Agencies," Federal Register vol. 74, no. 21 (February 3, 2009); Anthony Boardman et al., Cost-Benefit Analysis: Concepts and Practice (Prentice Hall, 1996); Barry C. Field, Environmental Economics: An Introduction (McGraw Hill, 1997); Bureau of National Affairs, OSHA and the Unions: Bargaining on Job Safety $\mathcal{E}$ Health (Bureau of National Affairs, 1973), quoting Bernard Kleiman; Alan B. Morrison, “OMB Interference with Agency Rulemaking: The Wrong Way to Write a Regulation," Harvard Law Review, vol. 99 (1986); Cass Sunstein, Risk and Reason: Safety, Law and the Environment (Cambridge University Press, 2002).

\title{
Is There a Moral Obligation to Limit Family Size?
}

\author{
Scott Wisor
}

A colleague tells a story about a graduate student who was passionate about the environment. Upon learning that his brother was considering having a third child, the student threatened never to talk to the brother again if he did have the third child because of the foreseeable detrimental environmental impact of that child's life. Surely the student would be wrong to cut off communication with his sibling. But was he correct in thinking that we ought to have small families for environmental reasons? I will argue that he was wrong on both counts.

For our purposes here, I will make two relatively uncontroversial assumptions. First, environmental degradation caused by human beings currently harms a very large number of human beings and threatens substantially to decrease the well-being and life chances of future human beings and other sentient beings. Second, among the many moral obligations that affluent individuals have, the obligation to protect the environment, prevent future environmental destruction, and when possible reverse past environmental destruction should be a high priority.

\section{The Argument for Limiting Family Size}

Bill McKibben has been a widely respected and prominent environmentalist for over three decades. $\mathrm{He}$, more than any other individual, has provided a sustained defense of the argument for limiting family size for environmental reasons. In his book Maybe One: A Case for Smaller Families, McKibben makes the argument that individuals ought to consider having 